The University of San Francisco

USF Scholarship: a digital repository @ Gleeson Library |

Geschke Center

Sociology

College of Arts and Sciences

2004

\title{
En-Gendering the Police: Women's Police Stations and Feminism in São Paulo
}

Cecília Santos

University of San Francisco, santos@usfca.edu

Follow this and additional works at: http://repository.usfca.edu/soc

Part of the Feminist, Gender, and Sexuality Studies Commons, Latin American Studies Commons, and the Sociology Commons

\section{Recommended Citation}

Santos, Cecília Macdowell. 2004. "En-gendering the police: Women's police stations and feminism in São Paulo." Latin American Research Review 39, No. 3: 29-55.

This Article is brought to you for free and open access by the College of Arts and Sciences at USF Scholarship: a digital repository @ Gleeson Library | Geschke Center. It has been accepted for inclusion in Sociology by an authorized administrator of USF Scholarship: a digital repository @ Gleeson Library $\mid$ Geschke Center. For more information, please contact repository@usfca.edu. 


\title{
EN-GENDERING THE POLICE: \\ Women's Police Stations and Feminism in São Paulo*
}

\author{
Cecília MacDowell Santos \\ University of San Francisco \\ Received 7-16-2003; RER 9-23-3003; \\ Received Revised 1-15-2004; Accepted 1-21-2004
}

\begin{abstract}
This article contributes to feminist state theory and studies of women's police stations in Latin America by examining the processes shaping the multiple and changing positions of explicit alliance, opposition, and ambiguous alliance assumed by policewomen regarding feminists since the creation of the world's first women's police station in 1985 in São Paulo. While studies of women's police stations tend to overlook the political conjuncture, much of the literature on the state and gender explains the relationship between the state and women's movements as a function of the political regime. I argue for a more grounded feminist state theory, taking into account interactive macro and micro, local and international forces. As this case study demonstrates, policewoman-feminist relations evolve due to interactions between the political conjuncture, the hegemonic masculinist police culture, developments in the feminist discourse on violence against women, and the impact of the contact policewomen sustain with women clients.
\end{abstract}

In August 1985 Brazil attracted the attention of international media for reasons other than the usual soccer championship, street violence, or Rio carnival. Media buzz centered on the Delegacia da Mulher (women's police station), a specialized police station run exclusively by female police officers, established by the São Paulo state government to investigate crimes of violence against women. The first women's police station

*This article is the result of extensive revisions on papers I have presented at the University of California, Los Angeles, and at the meetings of the Latin American Studies Association and the American Sociological Association. I thank David López and his graduate students, as well as Millie Thayer, for comments on a first and rough version of this article. I am also grateful to the anonymous LARR reviewers, Susie Dod Thomas, Aránzazu Borrachero, Laura Lyster, and especially Stephanie Sears for comments on earlier drafts of this article. Thanks also to Adriana Carvalho for her invaluable research assistance, Teresa Walsh for English revisions, the University of San Francisco for funding additional research, and the policewomen and feminist activists who generously gave me interviews. 
came about-despite Brazil's, and more specifically the police's, dominant machista culture - due to the political conjuncture ushered in by the process of redemocratization, which allowed feminists to demand successfully that the state treat violence against women as a crime. The women's movement effectively argued that the police, almost always men, rarely prosecuted cases of physical and sexual abuse of women.

With the establishment of this unprecedented institution in Brazil (and in the world), the state expanded women's rights, redefining an issue hitherto viewed as "private,". even "normal." The new institution also created new jobs for women on the police force. Thousands of women felt encouraged to report the violence that they had been suffering in silence and the number of complaints continued to increase over the years, giving greater visibility to violence against women. Hundreds of similar stations were opened throughout the country, and the new police station was immediately judged a success. ${ }^{1}$ Today, there are 125 women's police stations in the state of São Paulo, and 339 throughout Brazil. ${ }^{2}$

Although Brazilian feminists supported the new police station, it was a qualified support: from the beginning, feminists challenged the government's "separatist strategy," which was based on the essentialist assumption that female police officers would not oppose criminalizing violence against women and would be more sensitive to the needs of female victims of violence than male police officers would be, independent of their training. Studies of women's police stations have confirmed the initial feminist critique as well as the need for gender-sensitive training (Jubb and Izumino 2002; Nelson 1996; Santos 1999; Silva n.d.; Machado 2001; Massuno 2002; Muniz 1994; Conselho Nacional dos Direitos da Mulher 2001). Existing research, however, tends to homogenize the interests of policewomen and overlooks the broader political forces that shape policewomen's practices. Moreover, most research under-theorizes the complex and often contradictory relationships between policewomen and feminist organizations (for exceptions, see Nelson 1996; Santos 1999).

Based on in-depth, tape-recorded interviews with policewomen and feminist activists in the city of São Paulo, I have found that policewomen

1. During 1984 over 3,000 complaints of violence against women were registered in all regular police stations in the city of São Paulo. Between August 1985 and August 1986, the first (and then only) women's police station registered approximately 7,000 complaints and served over 65,000 women (Folha de São Paulo, August 6, 1986).

2. See Conselho Nacional dos Direitos da Mulher (2001); AGENDE, CLADEM Brasil et al. $(2003,30)$. Eight countries in Latin America (Argentina, Colombia, Costa Rica, El Salvador, Ecuador, Nicaragua, Peru, and Uruguay) have adopted some version of this Brazilian invention (Jubb and Izumino 2002). Countries in Europe, such as Portugal and Spain, as well as in Asia (e.g., Pakistan and India) have also established women's police stations (Station 1989; San Francisco Chronicle 1993; Oherald.com 2003). 
assumed three basic positions regarding feminists. ${ }^{3}$ In the first instance, I met policewomen who made explicit alliances with feminists, fully embracing the feminist discourse on violence against women. This position was predominant in the 1980s and regained prominence in 1994 and then again in the period between 1998 and 2000. Second, I encountered policewomen who opposed any contact with feminists and did not view violence against women as a "real" crime. Their position held sway in the early 1990s and reflected the hegemonic masculinist police culture. Finally, I met policewomen whose alliances with feminist organizations were indirect and ambiguous; they embraced aspects of the feminist discourse on violence against women but did not, or could not, make explicit alliances with feminists. This position was predominant in the mid-1990s and has prevailed since August 2001. These three positions have coexisted within the São Paulo Police Department since 1985one being more prominent than the others at particular times, as noted above. Also, I often found that individual policewomen held at least two of these positions over the course of a career.

What explains policewomen's divergent and changing relationships with feminists? More broadly, this question refers to the relationship between the state and women. Since Sonia Alvarez's (1990) groundbreaking book on feminist politics in the transition to democracy in Brazil, a new and expanding literature on the state and gender in

3. The data and ideas presented here draw on research I have conducted for my Ph.D. dissertation (Santos 1999) and for my forthcoming book on women's police stations in São Paulo (Palgrave-St. Martin's Press). I conducted in-depth, tape-recorded interviews with twenty-eight police officers (twenty-three females and five males) at various levels of the police organization in the city of São Paulo during different periods of research in 1994, 1995,1996 , and 2001. With the exception of two male police officers, all of the interviewees were working or had worked for the women's police stations, or had coordinated these stations. Among these, fourteen were delegadas de policia (female police delegates), eight were escrivãs (female police clerks), and four were investigadores (investigators, one female and three male). I also had numerous informal conversations with policewomen working in the nine women's police stations located in the city of São Paulo, all of which I visited in 1994. Moreover, I conducted in-depth, tape-recorded interviews with twenty-seven feminists involved with governmental and non-governmental organizations addressing the problem of violence against women. Among governmental organizations, I interviewed members (or former members) of the Conselho Estadual da Condição Feminina de São Paulo and Casa Eliane de Grammont. Among non-governmental organizations, I interviewed members (or former members) of the following: the extinct SOS-Mulher, União de Mulheres de São Paulo, Pró-Mulher, Coletivo Feminista Sexualidade e Saúde, GeledésInstituto da Mulher Negra, Casa da Mulher Negra, Coletivo de Feministas Lésbicas, Serviço de Orientação à Família-SOF, and CLADEM Brasil-Comitê Latino-Americano para a Defesa dos Direitos da Mulher. In 2002 and 2003, my research assistant, Adriana Carvalho conducted additional interviews with one policewoman and two feminists. In addition to interviews, this article draws on booklets, newsletters, and reports on violence against women and women's police stations published by the state and women's non-governmental organizations, as well as newspaper articles and legal documents. 
Latin America has emerged. Building on Alvarez's historical and politically contingent (not essentialist) approach to the state, there is a consensus in the literature that the state is not a monolith and does not have pre-determined, essential intentions regarding women or gender issues. Moving away from essentialism and structuralism, feminist scholars now conceptualize the state in Latin America as a "differentiated set of institutions" and a "site of struggle" both representing and reconstructing gender relations (Alexander 1991; Waylen 1996; Rai 1996; Schild 1998; Alvarez 1999-2000; Santos 1999; Molyneux 2000).

Feminist scholars explain the relationship between the state and women as "evolving and dialectic," contingent upon the historical and political conjuncture (Alvarez 1990; Waylen 1996; Rai 1996; Lievesley 1996; Metoyer 2000; Molyneux 2000). The "women's policy machineries," created in the context of redemocratization in Latin America since the 1980s, are good examples of how the state can foster both social control and social change in women's lives, depending on the political conjuncture. Scholars have shown, however, that these feminist institutions are fraught with contradictions. In addition to their limited power to influence other sectors of the state, they may disarticulate the women's movement by drawing key women organizers who become constrained by their positions within the state (Alvarez 1997; Schumaher and Vargas 1993; Friedman 1998; Schild 1998). ${ }^{4}$ That is why Alvarez $(1990,1997)$ aptly recommends that feminists develop multiple strategies to work both inside and outside of the state. Molyneux $(2000,67)$ also points out that the success of feminists in government depends on "strong linkages with those outside." In addition, "The degree of commitment to democracy more generally, the sympathy governments express toward women's issues, and the general direction of policy depend crucially on the party in power" (Molyneux 2000, 66).

Although showing that the state is not a monolith and does not have pre-established, essential intentions regarding women, this new literature has not completely moved away from a macro-level analysis. ${ }^{5}$ It is certainly true that the contradictory relations between policewomen and feminists in São Paulo are situated within the context of changing statesociety relations during the political transition to democracy in Brazil. However, even under governments controlled by the same party, policewomen have held conflicting interests and divergent positions with regard to feminism. As Sara Nelson (1996) asserts, these contradictory relations are the result of women's police stations being located within

4. See Franceschet (2003) for an alternative argument on the positive effects of the Chilean national women's policy machinery on the women's movement.

5. See Haney (1996) for a similar argument regarding the literature on the U.S. welfare state. 
the coercive and masculinist arm of the state. Therefore, by positing the relationship between the state and women as a function of the political regime or the party in power, feminist state theorists overlook the particular culture of the specific institutions with which women interact. In addition, they ignore the micro-level changes in civil society and the day-to-day interactions between state actors and their clients.

In this article I analyze the dynamics of the relationships between policewomen and feminists from both a macro and micro perspective. In particular, I examine the processes in the city of São Paulo that led to the emergence of a feminist police in the 1980s; the coexistence of a masculinist and feminist women police in the early 1990s; and a feminist versus gendered police since the mid-1990s. ${ }^{6}$ My analysis, which contributes to studies of women's police stations and feminist state theory, focuses on the interactions between the political conjuncture, the hegemonic masculinist police culture, the developments in the feminist discourse on violence against women, and the impact of the daily interactions policewomen sustain with women clients in the women's police stations. My goal here is to show that while the political conjuncture is important and shapes the practices of state actors, the dynamics of statesociety relations must be captured at both macro and micro levels of analysis. The fascinating and unique case study of women's police stations serves to illustrate this point and sheds light on the contributions and contradictions of institutionalizing a gender-based agenda through the creation of an all-female space within the repressive arm of the state.

\section{THE 1980S: CRIMINALIZING VIOLENCE AGAINST WOMEN AND BRINGING FEMINISM TO THE POLICE}

The politicization and criminalization of violence against women in Brazilian society was made possible thanks to the emergence of the second-wave women's and feminist movements of the 1970s. ${ }^{7}$ Concurrently, pressures from local and international social movement organizations led the military-authoritarian regime, in power since the 1964 military coup, to initiate a process of abertura politica (political opening) and a transition to civilian rule. This process both resulted from and contributed to the expansion of a mass-based women's movement (Alvarez

6. With one exception, no policewoman whom I interviewed identified herself as "feminist." They believed that feminists were radical, angry, and against men. But some were supportive of the feminist movement and openly in favor of establishing contact and learning from feminists working for governmental and non-governmental organizations. Because of their open alliance with feminists, I am calling them "feminist police."

7. See Alvarez (1990) for the most comprehensive account of the Brazilian women's movement in transition politics. For accounts by local activists, see Teles (1993); Soares (1994); Soares et al. (1995). 
1990). The United Nation's designation of 1975 as International Women's Year sparked an incipient transnationalization of feminism, which also fostered the expansion of the women's and feminist movements in Brazil. Feminist activists define feminism as "the political action of women. Feminism includes both theory and practice and centers on women as agents effecting change in their own condition.... The feminist movement is one segment of a large and increasingly heterogeneous women's movement that is creating opportunities for women's political participation" (Soares et al. 1995, 302). Although initially composed mostly of white, middle-class women, since the 1980 s the feminist movement has incorporated diverse segments of the women's movement, including working-class women from the periphery of large cities, rural workers, lesbians, and black women. They have fought for the expansion of citizenship rights, advocating new rights for women and new gender-based public policies (Soares et al. 1995).

Violence against women was one of the most important issues for the first Brazilian feminist groups (Alvarez 1990 and 1997; Teles 1993). In the late 1970s, feminist activists focused their attention on cases of wifemurder-not rare in Brazilian society-and organized numerous protests and campaigns on the issue. ${ }^{8}$ In the early 1980 s groups called SOS-Mulher (SOS-Woman) were created all over the country to provide social, psychological, and legal services to victims of domestic violence. They became the most influential groups with regard to the construction of the feminist discourse on violence against women, which they framed as the quintessential expression of patriarchy (Grossi 1988). These groups constantly faced sexist practices in police stations, which were run by mostly male police officers who did not take cases of violence against women seriously. The SOS-Mulher of São Paulo was created in 1981. Although extremely successful in attracting media attention, SOSMulher folded in 1983 due to changes in the political conjuncture, as well as internal disagreements over its structure (Gregori 1993).

In 1983 the opposition party Partido do Movimento Democrático Brasileiro (PMDB) gained control of several state governments, including São Paulo's. Feminist activists who worked in support of this party in the 1982 electoral campaign had the opportunity to work for newly established "women's machineries," such as the state councils on the status of women (Alvarez 1990 and 1997). In 1985 the PMDB won the

8. Wife-murderers were acquitted by the jury on the basis of the "honor defense" argument-a throwback to Portuguese colonial law that allowed a man to kill his adulterous wife and her lover (Americas Watch 1991). In 1991, the Brazilian Superior Tribunal of Justice (STJ) outlawed this argument, but later contradicted its own decision (Macaulay 2002). On the construction of the "honor defense" argument, see Corrêa (1981); Ardaillon and Debert (1987); Izumino (1998). 
federal government, and President José Sarney created the Conselho Nacional dos Direitos da Mulher (National Council on Women's Rights, or CNDM). ${ }^{9} \mathrm{He}$ staffed the Council with intellectual and middle-class feminists recruited from governmental and non-governmental organizations.

In the state of São Paulo, the newly elected PMDB governor, Franco Montoro, initiated institutional reforms based on principles of "participatory democracy," which called on social movement actors to work within the state in new hybrid state-society institutions where they would both design public policy and legitimate state authority. In 1983, Montoro created the Conselho Estadual da Condição Feminina (literally, the State Council on the Feminine Condition, or CECF), staffed by women state actors, feminist academics, and mostly middle-class feminist movement participants. Feminist activists were divided about participating in the new state. While some activists, including members of SOS-Mulher, favored participation, others feared that the movement would be co-opted. But given the unique opportunity, many activists ended up embracing the creation of the CECF (Alvarez 1990, 1997).

Strongly influenced by the practices of SOS-Mulher groups, violence against women soon became one of the priority issues of the Council. $\mathrm{CECF}$ feminists then devised a public policy that advocated providing female victims with "integrated services," and advocated this policy to Montoro. These "integrated services" included, among others, the creation of shelters and new institutions to provide legal and psychological services to victims of domestic and sexual violence, the anti-sexism training of police officers and the hiring of social workers in every police station, as well as the incorporation of the concerns of the women's movement into a gender-based public policy agenda (see Conselho Estadual da Condição Feminina 1984).

Montoro's Secretary of Public Security, Michel Temer, responded to the feminist demands by proposing the creation of an all-female police station. ${ }^{10}$ Temer overlooked the request for training, assuming that female police officers would not be sexist. On August 6, 1985, despite the

9. Sarney originally belonged to the rightist party PDS, which supported the military, but he had to join the PMDB in order to run for vice president with Tancredo Neves (PMDB), first civilian president selected by the Electoral College after the 1964 military coup. Due to health problems, Neves died right before taking office.

10. Unlike the United States, police stations in Brazil specialize in certain crimes, such as homicide and drug trafficking. Therefore, Temer's proposal was not so different from the local legal tradition. During the redemocratization period, other secretaries of public security also proposed new police stations specializing in racial crimes, crimes against elders, and environmental crimes. The major novelty of these stations was the state's recognition of the demands of new social movements, granting rights to social groups often excluded from access to justice. 
resistance of policemen in the police department, Montoro launched the first women's police station and charged it with investigating crimes committed against women. This new specialized police station exercised jurisdiction over cases of the crimes of actual bodily harm, threat of battery, battery, rape, as well as other crimes listed in the Brazilian Penal Code (Decree 23,769, August 6, 1985). In addition to exclusively investigating crimes against women, only female police officers could provide services to the female complainants.

Although feminists embraced Temer's proposal, they had reservations. As Cida Medrado, former member of the CECF, explained:

How could we think of a women's police station at that moment, when we were just emerging from a dictatorship? But we were aware that social workers did not have the power to register complaints. So we welcomed the creation of the women's police station. ${ }^{11}$

Rachel Moreno, co-founder of SOS-Mulher, further recalled that "Nobody was against the creation of a women's police station, but there was no proposal to create a shelter, for example. We thought that this station was insufficient to deal with the multifaceted problem of violence against women."12 Moreover, feminists did not share the essentialist assumption that policewomen would automatically be sensitive to their female clients. They successfully lobbied to include a paragraph in the legislation establishing that female police officers should attend seminars and lectures coordinated by the CECF and the São Paulo Bar Association (Portaria DGP 12, August 7, 1985).

\section{The Legal Ideology of Neutrality and the Masculinist Police Culture}

Feminists were particularly concerned about the legal ideology of neutrality and the dominant masculinist culture pervading the Brazilian administration of justice. In Brazil's legal tradition, the main goal of the judicial system is to "find the truth" neutrally and objectively through the correct interpretation and application of the law to each particular case. In both civil and criminal law, the judiciary-not a jury-is charged with "finding the truth" and relies on the interrogation, detection, and investigation carried out by the civil police to do so (Kant de Lima 1995). Every police station, and every investigation, is headed by a male delegado de polícia or female delegada de polícia (police delegate). The delegado/a, who is required to have a law degree, directs the inquêrito policial (police inquiry) with the help of investigadores (investigators) and escrivãos (police clerks), both of which are required to have a high school diploma. 
While the investigadores go out into the streets to conduct a service, arrest, or detect evidence, the escrivãos perform the administrative tasks of the police station. In order to enter each of these careers, police officers must pass a series of public exams on penal law, constitutional law, administrative law, and other branches of law. After passing their exams, police officers are required to complete a three-month course at the police academy. This training includes classes on criminology, legal medicine, constitutional law, telecommunications, human rights, child and adolescent, self-defense, and shooting. There are no courses on violence against women or on the women's police stations (Massuno 2002).

Although the work of the civil police supports the judiciary in "finding the truth" about allegedly criminal facts, they are independent of the judiciary and fall under the jurisdiction of the state's executive power. Both the judiciary and the police are presumed to be "neutral." This supposed neutrality rests on the separation of law and politics and of law and economics that is enshrined in Brazil's legal principles. The fact that the judiciary and the police are tenured civil servants is thought to guarantee this impartiality. Police officers and judges are presumed free from biases that would result from political pressures, economic interests, even their own gender, racial, or class prejudices. Neither the character of the crime nor the gender, race, or class of the alleged criminal or victim is supposed to influence the practices of police officers. As delegada Iraci Medeiros says, "We are trained to be police officers, the victim has no sex."13

The dominant police culture is masculinist in the sense that it does not consider violence against women to be a crime, or, if considered a crime, not one as serious as robbery, drug trafficking, or kidnapping. Furthermore, although women's police stations must investigate complaints initiated by women, the police academy does not include a seminar on violence against women in its three-month preparatory course for police officers. Recruitment of policewomen is not based on expertise on or commitment to reducing violence against women. There is no evaluation of policewomen's attitudes of respect or disrespect for their women clients.

In August 1985, responding to this supposed neutrality and the masculinist police culture, the CECF organized the first workshop on violence against women with the full support of Montoro's administration. This unprecedented meeting between police officers and feminists was attended by two hundred delegados and three delegadas. Feminists spoke about their analysis of violence against women being a result of patriarchy, as well as about their experience dealing with female victims of violence. Then president of the CECF, Eva Blay, voiced the feminist concern about the culture of police officers: "It is necessary that 
female victims press charges, but it is also necessary that police officers and judges do not reproduce patriarchal values when women initiate their complaints" (quoted in Diário Popular, August 16 1985).

Despite the alliance between Montoro's team and the women's movement, most policemen were not receptive to the feminist discourse on violence against women. As one delegado expressed:

I do not want to become a feminist. They are creating a war between men and women. Since the creation of this women's police station, policemen have been diminished and men have been portrayed as torturers. I think that the family's stability is more important than an actual bodily harm inflicted on a woman. (quoted in Jornal da Tarde 1985, August 16)

Although failing to institutionalize a course on violence against women in the police academy, the CECF was successful in organizing similar meetings and workshops with policewomen (not policemen) until the late 1980s. Many policewomen attended these events and developed an alliance with the CECF.

\section{The Emergence of a Feminist Police}

Before July 1985 only 1 percent of police officers in the state of São Paulo were women. There were 1,622 male police delegates and only 16 female police delegates (Tribuna Operária, July 9-15, 1985). The rapid expansion of these stations opened up new jobs for women and policewomen. Montoro established twelve additional women's police stations in the remaining sixteen months of his term, which ended in December 1986. Other states across the country immediately followed in the footsteps of São Paulo. By September 1986 there were twenty-three women's police stations throughout Brazil, and the CNDM was able to organize the first national meeting of delegadas (Conselho Nacional dos Direitos da Mulher 1986). However, women officers still comprised a minority within the police department and faced discrimination. This state of affairs made it possible, or necessary, for policewomen to seek out the support of feminists.

The alliance between feminists and policewomen prospered under the leadership of delegada Rosemary Corrêa, appointed to head the world's first women's police station. This was so despite the fact that Corrêa did not want to work for the new women's police station, at least at first. She held all the usual prejudices: she believed that being sent to the women's police station meant that her career was over. She did not perceive violence against women as a "real" crime and believed this was an issue to be dealt with by social workers, not police officers. She did not consider violence against women to be a visible problem in Brazilian society. And she believed, as the police asserted, that regular police stations did not discriminate against women clients. In short, Corrêa 
did not think that a police station specializing in crimes against women was necessary. ${ }^{14}$

As soon as Corrêa started running the first women's police station, however, her viewpoint changed. The day after the women's police station was inaugurated, Corrêa found herself facing a line of 500 women waiting to file complaints: "I saw that women lacked basic knowledge about their rights, and they were not heard anywhere else. I saw how important the work was, and I fell in love with it." ${ }^{15}$ Corrêa gradually changed her views on feminism-a movement she originally believed was "too radical" and "against men." She attended the seminars and meetings organized by the CECF and started to understand feminism as a movement struggling for women's rights. She began to publicly identify herself as a feminist. From feminists she learned that working at a women's police station demanded that policewomen perform more than a legal job; they should also develop sensibility, solidarity, and humanity.

Corrêa knew that many female police officers did not consider the women's police station a "real" police station and that most of them did not want to work in a women's police station for the same reasons she initially held. She learned, as the feminists taught, that being a woman was not enough to understand the situation of female victims. It was necessary to raise policewomen's consciousness. During her tenure as the head of the first women's police station she encouraged all female police officers to attend the seminars and workshops coordinated by the CECF. In addition, she saw the CECF as an ally to policewomen as they endeavored to empower themselves as policewomen vis-à-vis policemen.

Corrêa's personal and political transformation was not unique. Other officers told me similar stories, although they did not identify themselves as feminists. Investigator Ivete Ramos, for example, felt that she was not a police officer anymore when she was transferred from a regular police station to a women's police station in 1986. But the number of women reporting problems changed her views. As she recounted,

Although we had seen some cases in regular police stations, we had no idea about the gravity of the problem. It seems that all women decided to report when the first women's police station was opened, the lines were always enormous. ${ }^{16}$

Ramos was also influenced by the meetings and debates organized by the CECF, which she came to consider important to raise policewomen's consciousness. As she explained,

14. Interview with Rosemary Corrêa, São Paulo, June 16, 1994.

15. Ibid.

16. Interview with Ivete Ramos, São Paulo, April 24, 1994. Upon her request, I am using a pseudonym for this police officer. 
The oldest policewomen have not left the women's police stations, because we all ended up embracing the cause. If you interview my group, Dr. Izilda, Sílvia, Maria, Valdete, Dr. Rose, Maria Clementina, and others and others and others, [you'll see that] we embraced the cause. ${ }^{17}$

Although many who started working for women's police stations in the 1980s had contact with feminist groups through the CECF and "embraced the cause," it is important to note that not all of them supported an alliance with feminists, as I will illustrate later.

Gradually, policewomen gained power and visibility in society and in the police department. The female population was decidedly enthusiastic about these stations. Rede Globo, the largest Brazilian television network, ran a weekly serial named after the women's police stations. The media constantly interviewed policewomen and covered their work at the women's police stations. The number of these stations multiplied, jumping from thirteen to fifty-eight during the administration of Montoro's successor, Governor Orestes Quércia (PMDB, 1987-91).

In 1989, the police department created an Assessoria Especial das Delegacias de Polícia de Defensa da Mulher (Special Advisory Committee on the Police Stations in Defense of Women, or the Assessoria) to coordinate the work of the women's police stations in the state of São Paulo. Corrêa was selected to head the Assessoria, and in that capacity, she strengthened policewomen's ties with the CECF. In October 1989 Corrêa and all female police officers working in women's police stations in the state of São Paulo attended the first meeting of delegadas and their assistants organized by the CECF and the State Department of Public Security. At the time, there were over one hundred female police officers working in forty-two women's police stations.

Corrêa left the Assessoria in November 1989 to run for the São Paulo state assembly. After she left, the alliance between policewomen and feminists foundered, being reestablished in 1994 for a short nine-month period. Two divergent positions, one of opposition and one of alliance, were shaped by changes in the feminist discourse on violence against women and the nature of the democracy adopted by the local government.

\section{0-94: THE MASCULINIST VERSUS FEMINIST WOMEN POLICE}

In São Paulo in the early 1990s, the feminist discourse on violence against women changed in three major aspects, both facilitating and hindering alliances between feminists and policewomen. First, Brazilian scholars, influenced by U.S. and French debates, started to replace the

17. Ibid. Those whom Ramos calls "doctors" are police delegates, whereas the others are either investigators or police clerks. 
term "woman" with the term "gender," which they defined as a socially constructed category created through power relations between the sexes - therefore, not determined by biological differences between men and women (Heilborn 1992). "Gender violence" was seen as emerging from asymmetric and unequal power relations between the sexes (Saffioti 1994; Teles and Melo 2002). The use of "gender violence," a more neutral and scientific term than "violence against women," facilitated the incorporation of gender claims made by feminist organizations into public policy.

Second, the practice of consciousness-raising (a more grassroots process of acquiring a feminist consciousness and a gender identity) was replaced by the method of capacitação on gender (technical training with a critical perspective on gender aimed more at professionals in the areas of health and security). This shift happened in the context of what Alvarez (1998) identifies as the "NGOization" and "transnationalization" of feminist movements in Latin America. In the 1990s a growing number of feminist movement organizations, professionalized and specialized, transformed themselves into "non-governmental organizations" (NGOs) and increasingly dedicated themselves to intervening in policy processes on both national and international levels (Alvarez 1998). These trends proved to be double-edged. For example, the emphasis on the preparatory meetings preceding United Nations conferences in the 1990s temporarily distanced NGO professionals from local feminist mobilizations. At the same time, the participation of feminists in the 1993 United Nations Conference on Human Rights held in Vienna helped to revitalize local anti-violence struggles and launched the now internationally recognized assertion that "women's rights are human rights" (Keck and Sikkink 1998).

A third shift in the local feminist discourse on violence against women related to the emergence of a medical-therapeutic approach. In São Paulo, some local feminist NGOs working in the area of health, such as Coletivo Feminista Sexualidade e Saúde, began to incorporate violence against women into their agenda in the early 1990s. During the administration of progressive São Paulo mayor Luiza Erundina (1989-93), then affiliated with the Workers' Party (PT), members of Coletivo Feminista Sexualidade e Saúde and other feminist NGOs successfully developed social and psychological services for battered women at the Casa Eliane de Grammont, a governmental organization established by Erundina in 1990. Mayor Erundina opened a shelter in 1991, also run by feminists in charge of Casa Eliane de Grammont. ${ }^{18}$ In 1993, Coletivo Feminista Sexualidade e Saúde began to offer a series of courses of capacitação on

18. For security reasons, this shelter was closed in 1992 but only reopened in 2001, almost ten years later, by another female mayor from the Workers' Party, Marta Suplicy. 
gender violence from a public health perspective, mostly targeting health care providers and social workers.

These three changes accompanied and were shaped by two important changes in the national and local political situation: the adoption of neoliberal policies, also known as structural adjustment policies (SAPs), and a move from a participatory to a more formal democracy. In 1989 Brazilians chose Fernando Collor de Melo to be their first civilian president elected by direct ballot since the military coup twenty-five years before ${ }^{19}$ Collor opened the economy to foreign capital and cut public expenditures, especially in social areas, such as education, health, and public security. Collor also depoliticized instances where participatory democracy brought together state actors and social movement actors. Feminist members of the CNDM, for example, were replaced with women completely disconnected from, or opposed to, feminist movement organizations..$^{20}$ Yet even under these unfavorable conditions, the number of women's police stations continued to grow, and policewomen in São Paulo continued to hold two positions-opposition and allianceregarding feminism.

\section{Opposing Feminism (1990-93)}

The new governor of São Paulo, Luiz Antônio Fleury (1990-94), did not facilitate the participation of social movement actors in the state. Even though he belonged to the same political party (PMDB) as governors Montoro and Quércia, Fleury was a former delegado and prosecutor, and he made it difficult for feminists to challenge the masculinist police culture.

Delegada Carlinda de Almeida headed the Assessoria during this period and opposed any contact with feminists in the CECF. Almeida joined the police force in 1982, during the transition from military to civilian rule. She was the fourth woman in the state of São Paulo to pass the exam to become a delegado. She worked in regular police stations until the end of 1989 when she was appointed to replace Corrêa. She never wanted to work in women's police stations and managed to avoid doing so throughout her career, which means that she never worked directly with female victims. She could not, however, avoid the Assessoria.

Almeida's views on the women's police stations and on feminism did not change during her tenure in the Assessoria. When I interviewed

19. Collor was also the first Brazilian president to be impeached (due to corruption). His vice president, Itamar Franco (PMDB) became the president in 1993.

20. This situation persisted under the Itamar Franco administration (1993-94). State councils were openly critical of the CNDM. See Conselho Estadual da Condição Feminina de São Paulo $(1993,6)$. 
her in 1994, Almeida claimed that women's police stations discriminated against and segregated both policewomen and female victims. She also believed that women's police stations diminished the role of policewomen because the complaints they processed were "not criminal cases and did not belong to the police."21

Given Almeida's approach to violent crimes against women, it is not surprising that she did not see the need to include a course on violence against women in the police academy curriculum. Even if she favored such a course, feminists, in her view, should not be the teachers: "Policewomen are well trained in law schools and in the police academy. These feminists [in the CECF] do not have a law degree. They do not know what is right and wrong." ${ }^{22}$ Unlike Corrêa and her group, Almeida's contact with the CECF did not change her negative perception of feminists. Hence, she never encouraged policewomen to attend seminars or workshops on violence against women organized by the CECF. When she left the Assessoria, it was a relief not only to the CECF but also to her:

I had the opportunity to do other things and be a police officer again. I entered the police to do everything that men do, to be a police officer. Most women do not like to work with women's police stations, because they enter the police to do everything, to investigate crimes such as homicide. ${ }^{23}$

Despite the Assessoria's lack of interest and support, the number of women's police stations continued to grow. Because of the popularity of these police stations among the female population, politicians saw them as a tool to attract votes, and the government began to open new stations indiscriminately. In just three years, Governor Fleury created more women's police stations than any other São Paulo governor (46.4 percent of the total 125 women's police stations were established between 1985 and 2003). Yet the Police Department's disinterest had a great impact. The department did not provide the new stations with the minimum resources, both human and material, needed to do the job, much less specialized training for policewomen. In this context, it was not surprising to hear statements from policewomen that clearly undermined the original goals of the women's police stations. For instance, police clerk Mila Duarte expressed that, "Problems between husband and wife must be resolved at home. I'm very concerned about the family. I may regret the registering of a case later, because this may cause damage to the family. ${ }^{\prime 24}$ Duarte did not view rape in marriage as a crime either. She

21. Interview with Carlinda de Almeida, São Paulo, October 13, 1994.

22. Ibid.

23. Ibid.

24. Interview with Mila Duarte, São Paulo, September 22, 1994. Upon her request, I am not using the real name of this police officer. 
even blamed women for their situation. As she put it, "Many women are beaten up because they ask for it. I think she should take responsibility and defend herself. She was strong enough to speak up when she was provoking it. So she should fight back."

Hearing stories about this type of attitude, feminist activists felt disenchanted and the CECF criticized the services offered by the women's police stations (see Conselho Estadual da Condição Feminina de São Paulo 1993, 7). As Teresa Verardo, then coordinator of the CECF's Commission on Violence against Women, expressed:

Policewomen in the first women's police stations attended workshops organized by the CECF and they treated clients from a feminist standpoint. As politicians are opening more and more women's police stations without any concern about training, we have a problem rather than a solution. Policewomen are extremely machista. ${ }^{25}$

\section{Bringing Feminism Back In (1994)}

In April 1994 the CECF had the opportunity to work closely with the Assessoria again. Nineteen ninety-four was an election year, and Corrêa, running for state assembly for the second time, was able to use her political influence in the police department to replace delegada Carlinda de Almeida with delegada Izilda Ferreira, an old ally.

Ferreira entered the force as a police clerk in 1973, during the military regime. She became a delegada in 1983 and worked in a regular police station. In March 1986, still under Montoro's administration, Ferreira was transferred to a new women's police station opened in the west side of São Paulo. After eight years at that station, she was named to head the Assessoria, where she stayed from April 1994 until January 1995, only nine months.

Along with Corrêa and other officers from her group, Ferreira did not think at first that women's police stations were necessary. After working in the women's police stations, she felt overwhelmed by the number of cases and changed her position. Her attitude was also affected by on-going contact with feminists in the CECF. "In the beginning [in the mid-1980s] we didn't know that reality [the reality of female complainants], and we had to learn from experience. The CECF helped a lot; we would meet there and discuss our work." ${ }^{26}$ But, at that time, she still believed feminists were "too radical," meaning that they were not willing to negotiate. In contact with the CECF again in 1994, Ferreira found feminists "more mature and realistic about the possibilities for meeting their demands. ${ }^{27}$ 
The CECF's new "gender perspective," which first appeared in the 1994 bulletins of the CECF, helped to neutralize the "radicalism" of feminists in Ferreira's eyes. The CECF and the Assessoria, with Ferreira at the head, then created the Grupo Gestor da Política Estadual de Prevenção e Combate à Violência Contra a Mulher (Working Group on Public Policy to Prevent and Fight Violence against Women). One of the proposals of this working group focused on gender capacitação for those providing public services to female victims of violence. This proposal was particularly helpful to confront the prejudices of women who entered the police force during the 1990s. They did not want to work in women's police stations and felt they were put there as a form of castigo (punishment), which would keep them from moving up professionally.

Like Corrêa and Ramos, Ferreira also saw the CECF as an ally in the struggle against the discrimination that policewomen still faced within the police department.

We need each other because the women's police stations were the result of a struggle initiated by the CECF, and there are many things we [policewomen] cannot say, whereas they [feminists in the CECF] can. Thus, we need them to express our demands. But they also need us, because we are the source of statistics and information. ${ }^{28}$

Ferreira's positive view of the relationship between feminists and policewomen bore fruit. In June 1994 the State Department of Public Security sponsored a seminar, "A Delegacia de Defesa da Mulher Frente à Realidade Social" (The Police Station in Defense of Women and Social Reality). The seminar brought together almost all the delegadas from the 117 women's police stations in the state of São Paulo for the first time. The Secretary of Public Security, state assemblywoman Rosemary Corrêa, Ferreira as the head of the Assessoria, and the president of the CECF also attended.

Around the same time, the first course of Capacitação para Atendimento a Mulheres em Situação de Violência (Training for Providers of Services to Women in Situation of Violence) was offered by Coletivo Feminista Sexualidade e Saúde—one of the most important São Paulo NGOs focusing on women's health and reproductive rights. However, only two policewomen attended this course, Izilda Ferreira and her assistant.

Since the Assessoria could not require mandatory participation in workshops organized by feminist NGOs, and did not succeed in getting a course on violence against women included in the Police Academy's curriculum, it was unable to directly challenge the masculinist culture shaping the discourses and practices of the new policewomen working in the growing number of women's police stations. Ferreira became an 
outspoken critic of this masculinist culture; her criticisms were not appreciated, and she was removed from the Assessoria in January 1995 by the newly elected governor, Mário Covas, and the police department sent Ferreira to work in a regular police station.

\section{5-2003: THE FEMINIST VERSUS GENDERED POLICE}

Since the mid-1990s, relations between policewomen and feminists have developed in the context of a transnational feminism-a postBeijing, and other international conferences, world-in which international feminist politics impacts local feminist politics and vice-versa. Policewomen/feminist relations also have developed within a national and local conjuncture of neoliberal policies and a hybrid formal/participatory democracy.

At the Fourth World Conference on Women held in Beijing in 1995, violence against women was at the center of the feminist agenda, and this contributed to a strengthening of local feminist politics regarding this issue. Following in the footsteps of the Vienna Conference, the issue was framed as a violation of human rights, and therefore, an object of international criminal law (Keck and Sikkink 1998; Macaulay 2002). However, given the complexities of understanding and using international law to fight violence against women on a local level, feminist activists also framed it as a health issue (Keck and Sikkink 1998). In the post-Beijing period, these two discourses-on human rights and health-complemented each other, influencing the Brazilian government and local feminist organizations. ${ }^{29}$

The presidency of Fernando Henrique Cardoso also shaped feminist politics in Brazil during this period. Cardoso headed the ticket for a new party, Partido Social-Democrático Brasileiro (Social-Democratic Brazilian Party, or PSDB), and was elected for two terms (1994-98 and 19992002). The PSDB was founded in the late 1980s in São Paulo by Cardoso, Franco Montoro, and Mário Covas, who came out of the more socialdemocratic sectors of the PMDB. Despite the social-democratic name, the Cardoso government continued to implement the PMDB's neoliberal policies as dictated by the IMF, favoring the privatization of publicly owned companies and the retreat of the state from its social responsibilities. On the other hand, Cardoso adopted a hybrid formal/participatory democracy that included the participation of social movement actors in the design of social programs emphasizing human rights and racial

29. In the aftermath of Beijing, the CNDM launched the National Program to Prevent and Eradicate Domestic and Sexual Violence. In 1998 CLADEM Brasil-Comitê LatinoAmericano e do Caribe para a Defesa dos Direitos da Mulher launched the campaign Sem as Mulheres os Direitos Não São Humanos (Without Women, Rights Are Not Human). 
issues. The CNDM, for example, was re-staffed by highly regarded feminist scholars and activists.

In São Paulo, governor Mário Covas (PSDB) also favored the participation of social movement actors in the state councils. He received unanimous support from feminist organizations when he nominated a black woman (a first), Maria Aparecida de Laia, to be the president of the CECF. However, due to neoliberal policies, he also cut the staff of the CECF to less than one third of its original strength. The Assessoria received a new name, Serviço Técnico de Apoio às Delegacias de Polícia de Defesa da Mulher (Technical Service in Support of the Police Stations in Defense of Women, hereafter referred to as Serviço Técnico), but its role did not change. In this paradoxical political climate, the new head of the Serviço Técnico, delegada Maria Inês Valenti, moved from an initially ambiguous relationship with the CECF to an explicit alliance-but as soon as the alliance became explicit, still under the administration of the PSDB, Valenti was removed from the Serviço Técnico.

\section{From Ambiguous to Explicit Alliances (1995-2001)}

Maria Inês Valenti graduated from law school in 1988 when she was forty-two-years old. She passed the exam to become a delegada in 1989 during the administration of Quércia. Valenti divorced while attending law school, and she raised two children alone. She knew that she suffered through a terrible time, but only after working for the women's police stations was she able to name the conditions that led to her divorce-she came to realize that her husband had inflicted psychological violence on her. ${ }^{30}$

Like many other policewomen, Valenti did not favor the existence of specialized police stations for women at first. She thought that they discriminated against women. She also believed violence against women was not as serious as other crimes, such as robbery, drug trafficking, and kidnapping. "I wanted to be a police officer, processing serious crimes," she explained. ${ }^{31}$ However, just as with Corrêa, Ferreira, Ramos, and many others, her experience dealing with complaints initiated by female victims persuaded her that the women's police stations were necessary. When she entered the police force in 1989, she attended a few workshops organized by the CECF. (Corrêa was then the head of the Assessoria). She did not like to attend those workshops because feminists acted as if "they were in a war." Whenever the meetings were not mandatory, she did not attend. 
In 1995, newly appointed to head the Serviço Técnico, Valenti still harbored some prejudices against feminists, and she established an ambiguous alliance with the CECF. How she responded to the debates on the redrafting of the legislation on women's police stations illustrates this point. In December 1995 state representatives, judges, policewomen, and a few feminist activists met to discuss whether abortion and infanticide (as well as a few other crimes) should fall under the jurisdiction of the women's police stations. It is important to note that this would represent a significant shift since women are perpetrators, not victims, in cases involving abortion and infanticide.

The discussion was sparked by the new legislation establishing criminal small claims courts (Law 9,009, September 26, 1995), which defined "small claims" as those crimes carrying a prison term of up to one year. Since most cases processed in women's police stations fit this definition, policewomen feared that women's police stations would be closed, and they lobbied to expand the jurisdiction of these stations. With a few exceptions (such as Corrêa) the majority of policewomen, including Valenti, favored the change. For them, it did not matter that the women's police stations had been created to serve female victims rather than process female perpetrators. ${ }^{32}$

Yet Valenti also began to absorb aspects of the discourse on gender violence. In 1995 she attended the second course of capacitação on gender offered by the feminist NGO Coletivo Feminista Sexualidade e Saúde. This course, though emphasizing a medical-therapeutic approach to violence, influenced Valenti's understanding of "gender violence" and capacitação-new terms she was just starting to hear from feminists. Another police officer who attended the third course, delegada Maria Teresa Rosa, also learned for the first time about "gender violence," and she became a supporter of feminism: "I don't consider myself a feminist," she said, "but I favor and admire their work. Without them, we wouldn't have many institutions that are now serving women; and nobody would care about domestic violence, because our civil and penal codes are as patriarchal as our society." ${ }^{133}$ Valenti's and Rosa's experiences illustrate well one of the trends Alvarez points out in Latin American feminist politics in the 1990s, that is, the "absorption of (the more digestible) elements of feminist discourses and agendas by dominant cultural institutions, parallel organizations of civil society, political society and the state, and the international development establishment-all spheres in which feminists can today be found" $(1998,294-95)$.

32. In 1996 the jurisdiction expanded to include crimes of abortion, infanticide, homicide, and crimes against children and adolescents irrespective of gender. See Decree 40,693, January 3, 1996.

33. Interview with Maria Teresa Rosa, São Paulo, January 19, 1996. 
In the post-Beijing context, Valenti also absorbed aspects of the discourse on women's human rights. In March 1998, as part of the Campaign for the Human Rights of Women, the CECF organized, inpartnership with the State Department of Public Security (and the Serviço Técnico), the Primeiro Curso de Capacitação para Delegadas das Delegacias de Defesa da Mulher: Violência de Gênero (First Course of Capacitação for Female Delegates Working for Women's Police Stations: Gender Violence). This one-week course was mandatory for all delegadas of the existing 124 women's police stations in the state of São Paulo. Feminist scholars and activists from the CECF, CNDM, and feminist NGOs gave lectures addressing gender issues in relation to human rights, health, media, and so on.

By 1999 Valenti's explicit alliance with feminists was undeniable. She became the first policewoman to join the CECF. She did so as a "representative of civil society" (Conselho Estadual da Condição Feminina 2003). Then CECF president, Maria Aparecida de Laia, described their relationship as "good" and "harmonious." "We were able to bring the coordinator of the women's police stations to the board of the CECF," she said ${ }^{34}$ By joining the CECF, Valenti explicitly challenged the separation between her supposedly politically "neutral" role in law enforcement and her political-feminist role in civil society. In May 2001 she was removed from the Serviço Técnico and sent to perform administrative duties in a politically insignificant sector of the police department. According to some policewomen, Valenti's removal from the Serviço Técnico was a sort of castigo for her strong position in defense of women's police stations as well as her ties with the CECF. Valenti "went too far," they said. ${ }^{35}$ That is why the new head of the Serviço Técnico, Márcia Buccelli Salgado, has been careful to maintain a distant relationship with the CECF. In July 2003 the new president of the CECF, Aparecida Maria de Almeida, invited Salgado to participate in the CECF's monthly meetings. As Salgado did not seem to show interest in attending, the CECF's president sent a memo to the police chief and the secretary of public security soliciting her presence. Salgado is now forced to go to the meetings. ${ }^{36}$

This ongoing contact may help Salgado to develop an explicit alliance with feminists, especially now that the new federal government is fully supporting gender-based public policies, reforming the structure

34. Interview with Maria Aparecida de Laia, conducted by my research assistant, Adriana Carvalho, in São Paulo, April 8, 2003.

35. Information provided by my research assistant, Adriana Carvalh6, based on conversations she had with two policewomen in São Paulo, June 18, 2003.

36. Information provided by my research assistant, Adriana Carvalho, based on a conversation she had with Márcia Salgado in São Paulo, June 18, 2003. 
of and empowering the national women's policy machinery-an old demand of the feminist movement, and further promoting national measures to fight violence against women. In the beginning of 2003, newly elected President Luiz Inácio Lula da Silva elevated to ministerial status and renamed to Secretaria Especial de Políticas para as Mulheres (Special Secretary for Women's Public Policies), the Secretaria de Estado dos Direitos da Mulher (State Secretary on Women's Rights, or SEDIM), which had been created by former President Cardoso in May 2002 to function within the Ministry of Justice. ${ }^{37}$ In November 2003 the special secretary, headed by Minister Emília Fernandes, promoted a national meeting of female police delegates working for women's police stations, held in Brasília. Minister Fernandes also established a partnership with São Paulo's mayor, Marta Suplicy (PT), who opened a new center run by feminists in São Paulo to provide victims of domestic and sexual violence with social and psychological assistance.

\section{CONCLUSION}

Despite their limitations, the women's police stations in Brazil have promoted significant changes in women's lives. They opened up a job market for women. They expanded victims' citizenship rights, allowing them to denounce a violence that not long ago was invisible and considered a private matter. In 2000 , for example, 310,058 complaints of violence against women were registered in the women's police stations of São Paulo.$^{38}$ Nonetheless, existing research shows that very few cases go to court (Jubb and Izumino 2002). Researchers and police officers have reported that the São Paulo Police Department and other police departments throughout Brazil still discriminate against policewomen and women's police stations (Conselho Nacional dos Direitos da Mulher 2001; Silva n.d.). The lack of institutionalized gender-based training for police officers is an indication of the limits of creating a women's space within the repressive and masculinist arm of the state. This limitation is not simply a result of the lack of interest the government, or the party in power, has expressed towards women's issues in general and violence against women in particular.

37. The new special secretary has established partnerships with other ministries, state governments, mayors of major cities, and the women's movement to foster campaigns against violence against women, gender capacitação for policewomen, the creation of new women's police stations, and new psychological services and shelters, among other plans for action included in the Programa Nacional de Prevenção, Assistência e Combate à Violência contra a Mulher (National Program to Prevent, Assist, and Fight Violence against Women).

38. Data provided by Serviço Técnico de Apoio às Delegacias de Polícia de Defesa da Mulher do Estado de São Paulo. 
In addition to the political conjuncture, the interests of police officers are shaped by the legal principle of neutrality and by the masculinist culture of their concrete institutional base-the police. In the case of women's police stations, both internal and external actors, such as policewomen and feminists, have challenged this culture, even under the same political regime. Policewomen's daily experience working with female victims of violence has transformed, to a lesser or greater extent, their conception of the criminal nature of violence against women. Their legal culture has also been transformed by their interaction with feminists in the CECF and by the changing feminist discourses on gender violence, capacitação, and women's human rights, all in the context of the professionalization and transnationalization of feminism. The growing number of women's police stations has also empowered policewomen as a distinct gendered actor within the police department. In sum, the case of women's police stations shows that the state is not only a site of struggle and of differentiated and internally contradictory institutions, it is also "a complex of concrete institutions with which women interact in direct and immediate ways" (Haney 1996, 759; my emphasis). The relationship between the state and women is indeed evolving and dialectic, but it is more than a function of the political regime. It evolves due to multiple and interactive, macro and micro, local and global, processes.

In order to uncover these processes and develop a more grounded theory of the state and gender, it is necessary to conduct further ethnographic and comparative research on specific institutions with which women and feminists directly interact. Ethnography can help us grasp in concrete terms how the interests and culture of state actors are, or might be, transformed by interactions between state and civil society actors. It can also shed light on how the state actually "(re)posiciona a los sujetos femininos a través de sistemas interpretativos institucionalizados" (repositions female subjects through institutionalized interpretative systems [Alvarez 1990-2000, 62; my translation]).

Comparative and cross-national research on different institutional sites of the state would also further our understanding of how politics might interact with and shape specific institutional cultures differently. For example, in São Paulo, why has the health care system been more open to incorporating gender claims and working more closely with feminists than the criminal justice system $?^{39}$ Finally, studies of the state and gender tend to focus on feminist politics with regard to legislative and governmental policy processes. Yet the justice system is a

39. For an example of the successful feminist experience of incorporating the issue of violence against women into the health care system, see União de Mulheres de São Paulo (2000). 
crucial terrain for the advancement of democracy. As Caldeira (1998, 199) points out:

The constraints that limit the democratization of Brazil, as well as that of other countries in Latin America, are to be found in the areas of justice and individual rights, and in the popular conceptions of both, rather than in conflicts over the political regime among political actors and parties.

While progressive legislation has been enacted by newly democratic states in the region, the lack of law enforcement is a major impediment to the exercise of new rights. This is the case, as Macaulay $(2002,80)$ explains, "because of the lack of effective remedies and anti-remedies, and the structural flaws in the institutions of the justice system."

In the context of new emerging democracies and neoliberal states, the question for feminists and other social movement actors is no longer whether to enter or not to enter the state, but how to have their claims meaningfully incorporated by the state (Molyneux 2000, 67; Alvarez 1999-2000). Creating an institutional space for women, though important, is not sufficient to make meaningful change, as evidenced by contradictions in women's policy machineries run by feminists (Alvarez 1997; Schumaher and Vargas 1993; Friedman 1998; Schild 1998). The "separatist strategy" is even more contradictory when those occupying the space are policewomen not necessarily in alliance with feminists. Alvarez recommends that an effective feminist lobby would require the constant questioning of any "gender-based policy" adopted by a given state or the United Nations, a "re-translation" from inside and outside of the institutional lobbies (1999-2000, 63-6). This constant "translation," as the case of women's police stations suggests, is needed in all sites of the state, and must also take into account the specific cultures, structures, everyday work-related practices, and constraints of each institution with which feminists and women interact.

\section{REFERENCES}

AGENDE-Ações em Gênero, Cidadania e Desenvolvimento, Brasil-Comitê LatinoAmericano e do Caribe para a Defesa dos Direitos da Mulher (CLADEM)

2003 O Brasil e a convenção sobre a eliminação de todas as formas de discriminação contra a mulher: Documento do movimento de mulheres para o cumprimento da convenção sobre a eliminação de todas as formas de discriminação contra a mulher [Convention on the Elimination of All Forms of Discrimination against Women (CEDAW)]. Estado Brasileiro: Propostas e Recomendações. Brasília.

Alexander, M. Jacqui

1991 "Redrafting Morality: The Postcolonial State and the Sexual Offences Bill of Trinidad and Tobago." In Third World Women and the Politics of Feminism, edited by Chandra Talpade Mohanty, Ann Russo, and Lourdes Torres, 133-52. Bloomington and Indianapolis: Indiana University Press.

Alvarez, Sonia E.

1990 Engendering Democracy in Brazil: Women's Movements in Transition Politics. Princeton, NJ: Princeton University Press. 
1997 "Contradictions of a 'Women's Space' in a Male-Dominant State: The Political Role of the Commissions on the Status of Women in Postauthoritarian Brazil." In Women, International Development, and Politics: The Bureaucratic Mire, edited by Kathleen Staudt, 59-100. Philadelphia, PA: Temple University Press.

1998 "Latin American Feminism 'Go Global': Trends of the 1990s and Challenges for the New Millennium." In Cultures of Politics/Politics of Cultures: Re-visioning Latin American Social Movements, edited by Sonia E. Alvarez, Evelina Dagnino, and Arturo Escobar, 293-323. Boulder, CO: Westview Press.

1999-2000 "En qué estado está el feminismo? Reflexiones teóricas y perspectivas comparativas." Estudios Latinoamericanos 12-13:47-66.

Americas Watch

1991 Criminal Injustice: Violence against Women in Brazil. New York: Human Rights Watch.

Ardaillon, Daniele, and Guita G. Debert

1987 Quando a vítima é mulher: Análise de julgamentos de crimes de estupro, espancamento e homicídio. Brasília: Conselho Nacional dos Direitos da Mulher, Ministério da

Caldeira, Teresa Justiça, DF.

1996 "Crime and Individual Rights: Reframing the Question of Violence in Latin America." In Constructing Democracy: Human Rights, Citizenship, and Society in Latin America, edited by Elizabeth Jelin and Eric Hershberg, 197-214. Boulder, CO: Westview Press.

Conselho Estadual da Condição Feminina de São Paulo

1984 Boletim informativo.

1993 Voar é preciso. Boletim informativo do Conselho Estadual da Condição Feminina/SP 3 , no. 4 (December).

2003 Conselho Estadual da Condição Feminina: Sua história, suas lutas, seu futuro, 19832003. São Paulo.

Conselho Nacional dos Direitos da Mulher

1986 I Encontro nacional de delegadas lotadas em delegacias de defesa da mulher. Brasília.

2001 Pesquisa nacional sobre as condições de funcionamento das delegacias especializadas no

Corrêa, Mariza atendimento às mulheres: Relatório final. Brasília.

1981 Os crimes da paixão. São Paulo: Brasiliense.

Diário Popular

1985 "Secretário está satisfeito com a delegacia da mulher." August 16.

Folha de Säo Paulo

1986 "Delegacia da mulher completa um ano com sete mil ocorrências," August 6.

Franceschet, Susan

2003 “'State Feminism' and Women's Movements: The Impact of Chile's Servicio Nacional de la Mujer on Women's Activism." Latin American Research Review 38 (1): 9-40.

Friedman, Elisabeth J.

1998 "Paradoxes of Gendered Political Opportunity in the Venezuelan Transition to Democracy." Latin American Research Review 33 (3): 87-135.

Gregori, Maria Filomena

1993 Cenas e queixas: Um estudo sobre mulheres, relações violentas e a prática feminista. São Paulo: Paz e Terra.

Grossi, Miriam Pilar

1988 "Discours sur les femmes battues: Représentations de la violence sur les femmes au Rio Grande do Sul." PhD diss., University of Paris V, Department of Human Sciences.

Haney, Lynne

1996 "Homeboys, Babies, Men in Suits: The State and the Reproduction of Male Dominance." American Sociological Review 61:759-78.

Heilborn, Maria Luiza

1992 "Fazendo gênero? A antropologia da mulher no Brasil." In Uma questäo de gênero, edited by Albertina de Oliveira Costa and Cristina Bruschini, 93-125. São Paulo: Rosa dos Ventos. 
Izumino, Wânia Pasinato

1998 Justiça e violência contra a mulher: O papel do sistema judiciário na solução dos conflitos de gênero. São Paulo: Annablume.

Jornal da Tarde

1985 "Lotada, a delegacia da mulher cresce." August 16.

Jubb, Nadine

2001 "Enforcing Gendered Meanings and Social Order: The Participation of the National Police in the Nicaraguan Women's and Children's Police Stations." Paper presented at the International Congress of the Latin American Studies Association, Washington, D.C., September 6-8.

Jubb, Nadine, and Wânia Pasinato Izumino

2002 "Women and Policing in Latin America: A Revised Background Paper." Photocopy.

Kant de Lima, Roberto

1995 "Bureaucratic Rationality in Brazil and in the United States: Criminal Justice Systems in Comparative Perspective." In The Brazilian Puzzle: Culture on the Borderlands of the Western World, edited by David J. Hess and Roberto A. DaMatta, 241-69. New York: Columbia University Press.

Keck, Margaret, and Kathryn Sikkink

1998 Activists Beyond Borders: Advocacy Networks in International Politics. Ithaca, NY: Cornell University Press.

Lievesley, Geraldine

1996 "Stages of Growth? Women Dealing with the State and Each Other in Peru." In Women and the State: International Perspectives, edited by Shirin M. Rai and Geraldine Lievesley, 45-60. London: Taylor \& Francis.

Macaulay, Fiona

2002 "Taking the Law into their Own Hands: Women, Legal Reform and Legal Literacy in Brazil." In Gender and the Politics of Rights and Democracy in Latin America, edited by Nikki Craske and Maxine Molyneux, 79-101. New York: Palgrave.

Machado, Lia Zanota

n.d. "Eficácia e desafios das delegacias especializadas no atendimento às mulheres: O futuro dos direitos à não violência." Photocopy.

Massuno, Elisabeth

2002 "Violência contra a mulher: Delegacia de defesa da mulher, atribuições e problemas (1985-1998)." In Tratado temático de processo penal, edited by Marco Antonio Marques da Silva, 141-68. São Paulo: Juarez de Oliveira.

Metoyer, Cynthia Chavez

2000 Women and the State in Post-Sandinista Nicaragua. Boulder, CO: Lynne Rienner.

Molyneux, Maxine

2000 "Twentieth-Century State Formations in Latin America." In Hidden Histories of Gender and the State in Latin America, edited by Elizabeth Dore and Maxine Molyneux, 33-81. Durham, NC: Duke University Press.

Muniz, Jacqùeline

1994 "O direito dos outros e outros direitos: Um estudo sobre negociação de conflitos nas DEAMs/RJ." Photocopy. Rio de Janeiro: Instituto de Estudos da Religião (ISER).

Nelson, Sara

1996 "Constructing and Negotiating Gender in Women's Police Stations in Brazil." Latin American Perspectives 23 (1): 131-48.

Oherald.com

2003 "All Women Police Stations Working in India," May 27. http:// www.sameshield.com/news/awps.html (accessed December 15, 2003).

Rai, Shirin M.

1996 "Women and the State in the Third World." In Women and the State: International Perspectives, edited by Shirin M. Rai and Geraldine Lievesley, 15-22. London: Taylor \& Francis.

Saffioti, Heleieth Iara

1994 "Violência de gênero no Brasil atual." Estudos Feministas 2 (Special Number): 443-61. 
San Francisco Chronicle

1993 "All-Woman Police Station for Pakistan." December 21.

Santos, Maria Cecília MacDowell dos

1999 "The State, Feminism, and Gendered Citizenship: Constructing Rights in Women's Police Stations in São Paulo." PhD diss., Department of Sociology,

Schild, Verónica

University of California-Berkeley.

1998 "New Subjects of Rights? Women's Movements and the Construction of Citizenship in the 'New Democracies." In Cultures of Politics/Politics of Culture: Revisioning Latin American Social Movements, edited by Sonia E. Alvarez, Evelina Dagnino, and Arturo Escobar, 93-117. Boulder, CO: Westview Press.

Schumaher, Maria Aparecida, and Elizabeth Vargas 1993 "Lugar no governo: Alibi ou conquista?" Estudos Feministas 2: 348-64 (Fall).

Silva, Kelly Crisitane

n.d "As DEAMs, as corporações policiais e a violência contra as mulheres:

Soares, Vera Representações, dilemas e desafios." Photocopy.

1994 "Movimento feminista: Paradigmas e desafios." Estudos Feministas Special Number: 11-24 (Fall).

Soares, Vera, Ana Alice Alcantara Costa, Cristina Maria Buarque, Denise Dourado Dora, and Wania Sant'Anna

1995 "Brazilian Feminism and Women's Movement: A Two-Way Street." In The Challenge of Local Feminisms: Women's Movements in Global Perspective, edited by

Station, Elizabeth Amarita Basu, 302-23. Boulder, CO: Westview Press.

1989 "Confronting an 'Invisible' Issue." NACLA Report on the Americas 23 (2): 10-12.

Teles, Maria Amélia de Almeida

1993 Breve história do feminismo no Brasil. São Paulo: Brasiliense.

Teles, Maria Amélia de Almeida, and Mônica de Melo

2002 O que é a violência contra a mulher. São Paulo: Brasiliense.

Tribuna Operária

1985 "Um dia na delegacia das mulheres." July 9-15.

União de Mulheres de São Paulo

2000 Projeto: Implantação do serviço de atendimento aos casos de violência doméstica: Relato sobre a experiência no Hospital Pérola Byington. São Paulo: União de Mulheres de São Paulo.

Waylen, Georgina

1996 Gender in Third World Politics. Boulder, CO: Lynne Rienner. 
Copyright of Latin American Research Review is the property of Latin American Research Review and its content may not be copied or emailed to multiple sites or posted to a listserv without the copyright holder's express written permission. However, users may print, download, or email articles for individual use. 